\title{
Introduction: the role of government
}

\author{
Nikolaos Karagiannis and John E. King
}

The world economy remains highly 'unbalanced in ways that are destabilizing, exclusionary and dangerous for the political, social and environmental health of the planet' (UNCTAD 2017: iii). Even when economic growth has been possible, the gains have disproportionately accrued to small elites. At the same time, a combination of high levels of debt and inadequate demand at the global level has hampered sustained expansion of the world economy. Austerity measures adopted in the wake of the global financial crisis over a decade ago have compounded this vexing state of affairs (ibid.: iii). Indeed, the world economy remains marooned in a state of sluggish growth, while social and economic inequities show few signs of moderating. 'Governments have closed down egregious loopholes and toxic instruments exposed by the crisis; but however good their intentions, the reality is that few have been held accountable for their actions, and little has been done to tackle its root causes' (ibid.: i). Neoliberalism, at theoretical and policy levels, does not serve humanity.

Neoliberalism as the current worldview presents the competitive marketplace as the model for true human flourishing. And it has enjoyed success: from 'global competitiveness' on the world stage to individual practices of self-branding and social networking, neoliberalism has transformed many aspects of social life. Yet neoliberal globalization with the help of the very visible hand of the state has recovered its poise, business as usual has set in, 'light touch' regulations are generally being emphasized, and austerity has become the preferred response to 'excessively' high levels of public debt. At the same time, robots, rents and property rights are taking precedence over the livelihoods of people and their aspirations. Unlike the textbook world of 'pure competition', 'hyperglobalization' describes the dramatic change in the size, scope and velocity of globalization that began in the late 1990s and that has continued into the beginning of the 21 st century; is characterized by greater and deeper integration of global trade (world trade has become more dematerializing and has soared more rapidly than world GDP) and the control of multinational and transnational corporations; and has led to 
a considerable concentration of economic power and wealth in the hands of a remarkably small number of people (ibid.: iii; I).

But if history is any guide, it tends to generate political tensions that clash with wider public and social interests. Indeed, more clear-headed supporters of 'the market', since Adam Smith, have warned of the political dangers that can follow the concentration of economic wealth. It is therefore hardly surprising to find a popular backlash against a system that is perceived to have become unduly biased in favour of dominant transnational corporations, financial institutions and wealthy individuals. Neoliberal globalization and the information technology revolution, however, challenge old-fashioned areas of intellectual concern to discovery, explanation and theory, and require capable theoretical analyses along with thorough and pragmatic policy responses and interventions for achieving sustainable socio-economic development outcomes and advancing social progress (Davidson 2017; UNCTAD 2017).

Evidently, government is necessary to the existence of civilized society: it delivers basic services, manages the economy in uncertain economic times, and makes the big decisions for a nation's future. The government exercises executive, political and sovereign power through customs, institutions and laws within a nation, and sets and administers public policy. Policy intervention is action taken by governments that 'interfere' with decisions made by individuals, organizations and groups about social and economic matters. Capitalist market economies, however, are shaped by government activities, both in terms of actions and regulations and in terms of expenditure and income streams.

Libertarians, liberals and other advocates of free market or laissez-faire economics generally view government interventions as harmful, due to the law of unintended consequences, belief in government's inability to effectively manage economic concerns, and other considerations. Government officials tend to be naturally disposed to seek more power and authority (and the money that usually goes with those things), and this quest often takes the form of economic interventionism which they then seek to justify. Modern liberals in the United States and contemporary social democrats in Europe are inclined to support interventionism, seeing state economic interventions as an important means of promoting greater income equality and social welfare. Besides, political conservatives of the nationalist variety frequently support economic interventionism as a means of protecting the power and wealth of a country or its people, particularly via advantages granted to industries seen as nationally vital.

On the other hand, most Marxists argue that government welfare programmes might interfere with the goal of overthrowing capitalism and 
replacing it with socialism, because a welfare state makes capitalism more tolerable to workers. Besides, socialists often criticize interventionism (as supported by social democrats and social liberals) as being untenable and liable to cause more economic distortion in the long run. From this standpoint, any attempt to 'patch up' capitalism's contradictions would lead to distortions in the economy elsewhere, so that the only real and lasting solution is to entirely replace capitalism with a socialist economy.

It has been over a decade since the public sector was mobilized to save hyperglobalization through policy interventions, including quantitative easing, the absorption of bad debts, guarantees and, in some cases, expansionary public investment and spending policies.

Building the institutional structures and flexibilities in support of inclusive growth and development has become more challenging as the world has become more interdependent. Institutions for consultation, discussion and participation remain essential for generating the popular support needed to challenge the entrenched interests that have formed under hyperglobalization. To the extent that those interests are linked to global markets and firms, global rules and regulations are an urgent necessity. They are also needed in order to provide and manage global public goods that markets are unable or loath to deal with, including emerging threats and dangers related to a changing climate. (UNCTAD 2017: 163)

Each country should be able to decide where the boundaries are drawn between the state, private and social sectors; and developing countries seeking to catch up with those higher up the development ladder should be free to choose their own pattern of development, whether it be following in the footsteps of countries such as the United States, or Denmark, or China. Such freedoms of choice have been sidelined or abandoned altogether over the past 30 years under the dominance of a 'one-size-fits-all' policy agenda, to which no alternative has been considered viable or acceptable. In fact, even as these positions have softened, and the capture of policy-making by narrow interests challenged, one of the lingering features of hyperglobalization has been the application of business methods to social problems, which 'exaggerate what technology can do, ignore the complexities of social and institutional constraints, often waste sums that would have been better spent more carefully, and wreak havoc with the existing fabric of society in places they know very little about' (Mazower 2014: 417). Such business methods can have far-reaching exclusionary consequences, whether due to adverse selection or cherry-picking of the most profitable activities, leaving the chronic or expensive responsibilities to the state. 
Evidently, neoliberal measures have hit the world's poorest communities the hardest, leading to further polarization and heightening people's anxieties about their future. Yet

some political elites have been adamant that there is no alternative, which has proved fertile ground for xenophobic rhetoric, inward-looking policies, and a beggar-thy-neighbour stance. Others have identified technology or trade as the [causes] behind exclusionary hyperglobalization, but this too distracts from an obvious point: without significant, sustainable and coordinated efforts to revive demand by increasing wages and government spending, [national economies will continue to experience] sluggish growth, or worse. (UNCTAD 2017: iii)

It is clear that moving away from neoliberal globalization to inclusive economies cannot be a matter of simply boosting human capital, filling information gaps, improving incentives, ensuring better provision of public goods - particularly education - extending credit to the poor, and providing stronger protection to consumers. Rather, it demands 'a more exacting and encompassing agenda, [which can address] asymmetries in resource mobilization, technological know-how, market power and political influence' that are associated with neoliberal globalization and 'which generate and perpetuate exclusionary outcomes' (ibid.: xii).

The emergence of the persistent austerity of the financialized global economy is the outcome of modern policy choices based on faulty macroeconomics. In addition to continued austerity, a privatized state and declining democracy, the real threat now is to the underlying trust, cohesion and sense of justice that markets depend upon in order to function effectively. No social or economic order is safe if it fails to ensure a fair distribution of the benefits in good times and the costs in bad times. Insisting that 'there is no alternative is yesterday's political slogan' (ibid.: i-ii). 'People everywhere desire much the same things: decent jobs, secure homes, a safe environment, a better future for their children, and a government that responds to their needs and listens to their concerns' (ibid.: i-ii). In truth, they want a different reality from that offered by neoliberal globalization. What is still needed is a genuine return of the national state back in business, a supportive policy narrative, and bold political leadership. There are promising signs that some of the discarded strategies and solutions that helped rebuild the global economy after World War II are receiving a welcomed 21st-century makeover and are attracting fresh attention. This time, any new approach will need to 'lift all boats' in both developing and developed countries and face up to the challenge that many of the imbalances inhibiting sustainable and inclusive growth may be global in nature (ibid.: i-ii). 'Prosperity for all 
cannot be delivered by austerity-minded politicians, [powerful] rentseeking corporations, and speculative [financial institutions]' (ibid.: i-ii).

Revealing the philosophical and political shortcomings of the neoliberal ideal of freedom and 'challenging economic governance in an age of growing inequality' (Davidson 2017) call for progressive thinking and realism, a polity and economy characterized by a deepening of democracy that can ensure higher wages and higher living standards, and more engaged states that are also more accountable to their citizens. In reality, across today's increasingly interdependent world, the nation-state still remains

the basic unit of legitimacy and leadership, and one that citizens ultimately turn to for economic security, political loyalties and social cohesion. However, the capacities needed by the state to deliver these conditions have been eroded in many countries [due, at least] in part, to the heightened power of mobile capital and the policy overreach of market fundamentalists. The subordination of political leadership to the management, accounting practices and narrow profit orientation of private business interests has raised fears that the public sector too often shoulders the risks while the private sector captures the gains. (UNCTAD 2017: 147)

Moreover, 'there is potential to enhance the developmental impact of cooperation between the [government] and private sectors, but achieving this will require a clear distinction between private interests and broader public [goals], and addressing the tensions that inevitably arise between the two' (ibid.: 147). Just as in the past, today's circumstances will have to face the challenge of reclaiming and renewing the policy space in ways that offer an alternative to the short-term, predatory and often destructive behaviour of deregulated markets that provoke a popular backlash. Achieving this will clearly require a more proactive state, but it will also mean empowering politico-institutional structures to better mobilize and direct productive resources, and establish levels of cooperation and coordination to match the ambition required.

This edited volume, A Modern Guide to State Intervention: Economic Policies for Growth and Sustainability, seeks to investigate the impact of the changing role of the state, and offers an alternative political economy for the third decade of the 21st century. Present-day capitalism has generated growing inequality of income and wealth, persistent high levels of unemployment, and ever-diminishing prospects for young people. But in the absence of a positive vision of how society and the economy might develop in the future, the present trajectory of capitalism will never be derailed, no matter how acute the critique of present-day developments. Some areas of debate are: (i) ending austerity as a basic prerequisite for 
building sustainable economies and inclusive societies; (ii) major public works programmes with a strong caring dimension which can enhance public investment; (iii) raising government revenue based on the fundamental principles of social justice and 'ability-to-pay' in order to effectively address business tax avoidance and widespread use of loopholes; (iv) crowding-in productive investment requires taming financial institutions to make them serve broader social, economic and developmental goals; (v) measures that curtail restrictive business practices need to be strengthened considerably if corporate 'rentierism' and speculative attacks are to be substantially reduced; and (vi) enhancing policy space and strengthening the voice of organized labour and other social forces (especially the deprived, marginalized and powerless groups) (ibid.: 157-161).

In complete contrast to neoliberalism's destructive features and undesirable socio-economic outcomes, the Modern Guide to State Intervention argues that now is the ideal time to crowd-in private investment with the help of a concerted fiscal push to boost growth again and, at the same time, help rebalance economies and societies. Seventy years after J.M. Keynes's death, in another era of financial crisis and economic slump, interventionist ideas - which clearly require greater policy space - have made a comeback in economic circles. However, in today's world of mobile finance and liberalized economic policies, an individual country may not be able to do this on its own without risking capital flight, a currency collapse, and the threat of a deflationary spiral. What is needed, therefore, is a set of coordinated strategies of expansion led by increased public expenditure, with all countries being offered the opportunity of benefiting from a simultaneous boost to their domestic and external markets. With the appropriate combination of resources, policies and reforms, national economies have the tools available to galvanize the requisite investment push and demand growth needed to promote sustainable and inclusive outcomes at both global and national levels (Davidson 2017; UNCTAD 2017).

Significant long-term investments that enable expansion in lower income countries could be one means of reviving demand globally. It is, therefore, encouraging that Germany has recently announced its intention to launch a Marshall Plan for Africa. However, neither the scale nor the intent appears to match the original model that helped to rebuild post-war Europe. By contrast, China's 'One Belt, One Road' initiative seems more ambitious. If implemented as planned, the investments involved will be huge: an estimated $\$ 900$ billion. So far, much of the project is on the drawing board, and the pace of implementation as well as its impact will depend on how China manages its domestic imbalances, and on the mode 
of financing the proposed investments in participating countries (UNCTAD 2017: 56).

Moreover, industrial policies, as interventionist measures, are official strategic efforts to encourage the development and growth of part or all of the manufacturing sector as well as other sectors of the economy. The government takes measures aimed at improving the industrial capabilities and competitiveness of domestic firms and promoting structural transformation. Consequently, many types of industrial policies contain common elements with other types of interventionist measures such as trade policy and fiscal policy. However, industrial policies are sector-specific, unlike broader macroeconomic policies. Examples of the latter economywide policies are tightening the regulation of credit and taxing capital gains. Traditional examples of industrial policy that involve vertical, sector-specific policies include protecting infant industries from imports and subsidizing exports. More recent industrial policies include measures such as support for linkages between firms and spending on upstream technologies.

\section{THE STRUCTURE OF THE MODERN GUIDE TO STATE INTERVENTION}

The Modern Guide to State Intervention discusses various alternative theoretical approaches, sustainable growth-inducing economic policies, and proposals to address special challenges in this era of neoliberal globalization and financialization. These perspectives and policies have to be boldly and seriously considered if appropriate administrative and economic interventions towards changing the status quo of modern societies are to be pursued. With important contributions by distinguished academics, the book evaluates past efforts and policies, criticizes failed perspectives, and offers alternative strategies, policies and realistic options to address the current global socio-economic impasse. While different areas of concern are addressed, the chapters are informed, to a greater or lesser extent, by such important factors as history, the role of institutions (including market and government), society, economic structures and polity, which clearly stand in contrast to the starry eyed analysis of the current orthodoxy. Overall, the contributions to this edited book not only expand the body of knowledge but, more importantly, provide a rich menu of alternative strategies and policies.

The volume is structured around three main themes - which are also the titles of the three parts of the book. Part I, 'Philosophical and Theoretical Aspects', contains Chapters 1 to 4. In the opening chapter, 
Wolfram Elsner discusses the notions of 'complexity economics' and 'complex adaptive systems', addressing briefly structures, mechanisms, critical factors and dynamic properties. By focusing on an evolutionaryinstitutional perspective, the author considers implied requirements for the state, and introduces the idea of new meritorics, coinciding with long-standing pragmatist-instrumentalist policy conceptions and the qualifications the state itself would need to develop. In Chapter 2, Nikolaos Karagiannis, Zagros Madjd-Sadjadi and Joanna Bens provide an overview of the state and its various functions, and discuss the changing role of government during the 'era of change'. The authors critically examine the developmental state argument and offer important economic and politico-institutional aspects of what they believe to be desirable modern policy intervention. Chapter 3 by Malcolm Sawyer focuses on the fiscal responsibilities of governments and the nature of the objectives to be achieved through fiscal policies, examines the nature of the government budget position (deficit or surplus), and considers the difficulties and constraints of using the budget position to achieve full employment. However, government spending has to be financed in the sense of the agency undertaking the expenditure being in prior possession of purchasing power. In Chapter 4, Jan Toporowski reviews important monetary theory and policy notions, and discusses monetary policy setting, endogeneity, and the structure of financial markets. By examining the main reasons that can lead to monetary policy failure to influence economic decisions, the author strongly advocates those structural connections between financing and monetary policy that make monetary policy endogenous and are exactly the ones that are relied upon in alleviating financial instability.

Part II, 'Macroeconomic Policies for Sustainable Growth and Prosperity', comprises Chapters 5 to 9. In Chapter 5, Amitava Krishna Dutt introduces fiscal policy into simple models of growth and income distribution between workers and capitalists, including models with full employment growth, classical-Marxian models, and models in which aggregate demand influences economic growth. The models are first analysed for the case of a balanced fiscal budget in which all government spending is on government consumption, and are then extended to examine government deficits and the dynamics of government debt, and public investment which affects productivity growth. According to Dutt, the models imply that fiscal policy expansion is not necessarily associated with adverse effects of growth and income distribution, and that the effects depend on the structural conditions prevailing in the economy. In Chapter 6, Nikolaos Karagiannis and Zagros Madjd-Sadjadi briefly 
discuss developmental intervention experiences that took place in different countries and continents, and critically examine the successful East Asian industrial growth model. Singling out important theoretical notions within the Post Keynesian and radical political economy traditions and the 'right' lessons, and cautiously considering the present dismal socioeconomic environment, the authors offer general, but nevertheless important, realistic development policy areas based largely on the developmental state argument in a modern context while paying particular attention to public investment with a strong caring dimension. Chapter 7 , by Torsten Niechoj, analyses the emergence of the modern welfare state based on the writings of Marx and Polanyi - as a response to the evolution of market society, and describes the provision of welfare as a collective action problem which is solved by a state that takes responsibility for welfare. The author focuses then on the character of welfare as interventionism, and discusses and weighs liberal arguments against welfare. In Chapter 8, Sergio Rossi presents the mainstream and conventional view that considers money to be 'neutral' on real magnitudes and attributes to monetary policy the single goal of price stability. The author then elaborates on monetary targeting/inflation targeting strategies, which have resulted in output and employment losses and have contributed to inflating credit bubbles that, eventually, led to financial crises of a systemic nature. Rossi recommends that monetary policy should aim at financial stability as well as higher employment, abandoning the dogma of central bank independence. Chapter 9 by Heinrich Bortis discusses the principles underlying neoclassical and classical-Keynesian analyses, and singles out important employment mechanisms which are inherent in the latter. These mechanisms are then used to analyse the presently existing situation on a global level, and to formulate sensible distribution and employment policy principles along classical-Keynesian lines on the basis of the internal employment mechanism.

Part III, 'Special Issues and Policy Interventions', consists of Chapters 10 to 14. In Chapter 10, Romar Correa uses the classic book by Godley and Lavoie (2007), which is close in letter and spirit to the circuit approach in the scrupulous attention paid to national income accounting. The author then brings the systems approach to Godley and Lavoie sub-models, following their practice, and expresses his concern with the stability of different mixes. Correa incorporates a class orientation to fiscal policy, following the appeal of the stock-flow-consistent modelling strategy. Chapter 11, by Philip Arestis, presents the convergence Maastricht criteria and discusses briefly the theoretical framework that underpins the euro model while placing emphasis on the issues of the fiscal and monetary policies of the Economic and Monetary Union (EMU). The 
author highlights some of the policy faults that lie at the heart of the euro, and raises the question of 'whether the euro can be saved'. A positive answer requires political integration in the absence of economic integration in the European Union. Chapter 12, by Jesus Ferreiro, analyses the role played by wages in the Post Keynesian approach, and discusses conditions that favoured the implementation of wage policies in Europe during the 1990s. Considering the decline of wage policies after the creation of EMU, the author focuses on the potential role to be played by these policies in the current economic situation. Besides, along with an increase in aggregate demand, a full-employment agenda is necessary. Chapter 13, by L. Randall Wray, Flavia Dantas, Scott Fullwiler, Pavlina R. Tcherneva and Stephanie A. Kelton, focuses on guaranteed jobs through a public service employment programme for the United States, since generating good-quality employment is necessary for economic recovery, redistribution, and the future social sustainability of the country's growth trajectory. The authors remind us that, in both developed and developing economies, a high level of employment is clearly one of the most important ways of mitigating inequality and alleviating poverty, given that public service employment raises wage incomes, boosts aggregate demand and counters deflationary pressures. In addition, decent work, which has social, civic and creative implications, is an essential feature of an inclusive society. In the last chapter of the book, Denise Pearson examines the potential impact of minority-serving institutions, specifically historically black colleges and universities for state policies with equitable education as an outcome. The author discusses important concepts and policy recommendations through the lenses of 'equity' and 'critical race theory', incorporating the role of 'implicit bias' and the 'permanence of racism' in the United States and advanced Western countries and utilizing a critical race theory framework as necessary to better understand and challenge the ways race and racism, implicitly and explicitly, affect educational policy outcomes for states, students and institutions. According to Pearson, this clear focus should help us better understand racism and its systematic subordination of certain communities of minorities.

Our task would have been incomplete if we had not acknowledged those who kindly aided us in completing this book. We wish to thank the advisors and staff of Edward Elgar who have provided excellent support throughout the preparation of this manuscript, and the distinguished contributors for their willingness to participate and respond to our comments and suggestions despite philosophical differences regarding important notions such as the role of 'policy' and the role of 'intervention' in a capitalist economy and society. For instance, Randall Wray 
asserts that 'governments don't intervene. They are the foundation on which any successful capitalist economy is based'. Others (Nikolaos Karagiannis et al.) maintain that 'not only are governments the foundation for any successful capitalist economy but they also intervene. That's why we talk about macroeconomic (fiscal, monetary) policies, industrial targeting and development planning - among other forms of government activism'. All these intellectual differences are valuable and healthy, as they promote genuine pluralism in academia. We would also like to acknowledge the Trade and Development Report 2017, published by the UNCTAD, and to thank the Levy Economics Institute of Bard College for kindly permitting the combination of Policy Note 2018/3 and Research Project Report April 2018 to appear as Chapter 13 in the Modern Guide to State Intervention. Last, but not least, we thank our families for their continuous support and encouragement, and our students for the inducements. We owe them more than we can recount.

October 2018

\section{REFERENCES}

Davidson, P. (2017), Who's Afraid of John Maynard Keynes? Challenging Economic Governance in an Age of Growing Inequality, Basingstoke and New York: PalgraveMacmillan.

Godley, W. and M. Lavoie (2007), Monetary Economics: An Integrated Approach to Credit, Money, Income, Production and Wealth, Basingstoke and New York: PalgraveMacmillan.

Mazower, M. (2014), Governing the World: The History of an Idea, London: Penguin Books.

United Nations Conference on Trade and Development (UNCTAD) (2017), Trade and Development Report 2017 (Beyond Austerity: Towards a Global New Deal), New York and Geneva: United Nations. 